\title{
Populism, is it Democracy's Bastard or Twin? The Case of the European Union
}

\author{
José Filipe Pinto ${ }^{1}$
}

Received: 25 April 2017/Accepted: 6 June 2017/Published online: 27 June 2017

(C) Fudan University and Springer Nature Singapore Pte Ltd. 2017

\begin{abstract}
What do we mean when we say populism? Is populism a threat for democracy or a contribution to improve a system whose performance falls below our expectations? This essay seeks to find an answer to these questions. Keeping the available literature in mind, it shall reflect on populism myths before presenting a new concept of populism. A concept based on fight for hegemony. The essay argues that, on one hand, there is no democracy without populism, and on the other hand, populism can represent both a threat and a chance for democracy. Moreover, it shall analyze the reality of populism and democracy in the European Union by crosschecking the data of the Authoritarian Populism Index and the Democracy Index, without forgetting the last reports on the citizens' satisfaction degree with the functioning of democracy and per capita income. This is a relevant theme at a time when the populist parties have popped up in some democracies, share, or occupy the power in some EU countries, and in one case both the ruling party and the one leading the opposition are of populist nature. A populist democracy.
\end{abstract}

Keywords Democracy · Populism · Authoritarian Populism Index · Democracy Index

\section{Introduction}

Value judgments on the relations between populism and democracy represent one of those cases in which the sentence dictated by the published opinion seems to render the judgment irrelevant. Populism is usually presented as a threat to democracy, a

José Filipe Pinto

jose.pinto@ulusofona.pt

1 Department of Political Science, Security and International Relations, Lusophone University of Humanities and Technologies, Campo Grande 376, 1749-024 Lisbon, Portugal 
danger for the democratic institutions, as it is considered to be no more than a loose speech that only proposes false solutions for the social problems, whose complexity it cannot understand. This was the reason for Mariano Grondona's brief comment some decades ago: populism likes poor people so much that it multiplies them.

This remains the dominant idea among the ruling politicians in European Union. In 2010, the first President of European Council, Herman van Rompuy, identified populism as the greatest danger for Europe. However, since science is made of concepts and not of prejudices, perhaps, it may be opportune to go beyond this reductionist vision, characteristic of the common sense. A journey to the origins, that is to say, the search for the definition of populism.

Indeed, as Ferdinand de Saussure taught long back, each significant has a meaning associated with it. Populism is not an exception. Therefore, it matters to know the real meaning of populism, because as Pappas (2014:2-3) defends, each author looks at it in his own way: "as an ideology (Laclau 1977'; Mudde 2004²), a style of politics (Knight 1998), ${ }^{3}$ a specific discourse (Hawkins 2009) ${ }^{4}$, or a political strategy (Weyland 2001)" ${ }^{5}$. Obviously, the list could be extended.

Without some clarifications, we cannot have a conceptual construction. The word will go on having vague and abusive uses, as Laclau (2015) alerted us. That is why he spent much time to work out a Theory of Populism. An essential step to prevent the myths from dictating the law. A kind of self-satisfaction with a false security that cannot succeed when it faces the least questioning. Now, it is time to present a clearer definition of populism.

\footnotetext{
1 Laclau (1977:194) defends that "'populism arises in a specific ideological domain: that constituted by the double articulation of political discourse. The dialectical tension between 'the people' and classes determines the form of ideology, both among dominant and dominated sectors".

2 Cas Mudde has insisted on this position. In 2017, in Populism: a very short introduction, written with Cristobal Kaltwasser, on the page 32 of the Portuguese edition he defends that, adopting an ideational approach, populism can be defined as a thin ideology (Mudde and Kaltwasser 2017).

3 In the abstract, Alain Knight says: "This article reviews some of the literature, suggesting that populism is best defined in terms of a particular political style, characteristically involving a proclaimed rapport with 'the people', a 'them-and-us' mentality, and (often, though not necessarily) a period of crisis and mobilisation; none of which makes it exceptional, abnormal, 'unmediated', or irrational".

4 The author, in the abstract, explains that the article "pushes forward our understanding of populism by developing one of the more underappreciated definitions of populism, populism as discourse. It does so by creating a quantitative measure of populist discourse suitable for cross-country and historical analysis".

5 Later, Kurt Weyland would repeat this position saying that "Chávez and his friends used populism to entrench their predominance and install competitive authoritarian regimes. Populism, understood as a strategy for winning and exerting state power, inherently stands in tension with democracy and the value that it places upon pluralism, open debate, and fair competition. Populism revolves around personalistic leadership that feeds on quasi-direct links to a loosely organized mass of heterogeneous followers. Bypassing or subjugating intermediate institutions such as firmly organized parties, the leader-often a charismatic figure-establishes face-to-face contact with large numbers of citizens" (Weyland 2013:20).
} 


\section{Defining Populism}

To start, the word "people", the basis of populism, has several meanings. For Adriano Moreira, in the preface Pinto (2017), as the words are temperamentally uncertain, the expression is used at times to convey compassion and at other times to endow political dignity to the communities of citizens or voters. Indeed, le petit peuple toujours malheureux, a creation of Robespierre, was followed by what Karl Marx would call proletariat, "moving away the pejorative sense and giving ideological value to it". The people as construction: "we" opposed to "they", the others.

A conceptual construction carrying both an internal and an external dimension. An internal dimension, because the concept does not include the domestic privileged class, the elite or the chaste whose predatory action is denounced by the populist leaders. An external one, because it does not accept Terence's wordsHomo sum, humani nihil a me alienum puto — as it conceives "the other" as a threat for the maintenance of the national identity. The external dimension helps to understand the exacerbated nationalism and the manifestations of xenophobia and racism, while the internal one constitutes a fertile ground for populism.

The several meanings of the term "people" are responsible for the existence of so many definitions of the concept, implying that some of them do not refer to the same phenomenon, but to different realities. Granting that populism was born in Russia in the nineteenth century, the era of the Czars, as a reaction to the dangers of industrialization process, I believe that the origin of populism must be found in an earlier date, because it should not be considered as a democratic bastard, but as democracy twin brother, or as Canovan (1999) said, populism follows democracy as its shadow.

Canovan's typology of populism ${ }^{6}$ merited a very positive analysis by Taggart (2003:4), considering that it offered "the most ambitious attempt to get to grips with populism" as "she draws back from seeing populism as unified, and rather offers a key differentiation between agrarian populism and political populism". This opinion was rejected by Laclau (2005:19) because of the lack of a coherent criterion ensuring that the two categories_-agrarian and political populism-do not overlap. An endless quarrel despite some common points of view. Each researcher conceives populism differently. That is why Laclau was very critical not only relatively to Canovan but also to Donald (1969) and Wiles (1969) for example.

For me, populism represents a way of fighting for hegemony. A process that demands, as Laclau advocated and Chantal Mouffe still defends, ${ }^{7}$ the creation of an

\footnotetext{
${ }^{6}$ Laclau (2005:8) considers that Canovan distinguished between the agrarian and the political populism. In the earlier case, she included three types of populism: the agrarian radicalism (such as the case of the People's Party in the USA), the peasant movements (such as the Green Movement in East Europe, and the agrarian intellectual socialism (like the narodniki). In the latter case, Canovan included four types: the popular dictatorships (like that of Peron), the populist democracies (like the referendums and the participation), the reactionary populisms (like that of George Wallace and his followers), and finally, the populism of politicians (like the construction of ideological coalitions that benefit from the unifying appeal to People.

7 In several interviews, articles, and conferences, for example, in October 2016, in a conference held in Portugal, debating with Jean L. Cohen from Columbia University, she defended that more left populism
} 
antagonism based on the change from the differencialist logic, that of the ruling authority, to an equivalential logic that conceives people as the agent, not always coincident on the receiver condition of the change. People fail to recognize elite authority, because the ruling class often refuses to satisfy popular demands.

On this point, it is important to emphasize that both the people and the elite are no more primary elements, but illusory "re-creations" conceived as homogeneous, in spite of the differences they carry inside them. No questions are raised, because the homogeneity of both the concepts becomes useful to draw an internal border between only two antagonistic fields. Antagonism and fight never end, because when a leader reaches power he institutionalizes his model, but whichever the new paradigm, it will not be inclusive, because the meaning of people and population will remain separated, even when the new leader speaks in the name of people.

That is why populism follows democracy like a shadow. They usually do not go hand in hand, but democracy feels that it is never alone. Although Pareto (1917) has looked at History as a cemetery of aristocracies, there is no doubt that the elite, as Phoenix, proves to have an enormous capacity to be reborn. Such are the myths as we shall see them.

\section{The Myths of Populism}

Pappas (2013) pointed to the existence of three myths concerning to populism and tried to dispel these false narratives. The first of these myths defends that populism is an ideology, however, a "thin" one. The second one considers populism an extreme right-wing phenomenon. The third myth signs the existence of a close relationship between populism and the charismatic leadership.

This article is not the right place to present the arguments that Pappas used to break up these myths, but it is important to say that, at least in what concerns to the second narrative, the deconstruction process is easy, because assigning the populist responsibility only to the extreme right represents a serious mistake. Indeed, if there are extreme-right populist movements and parties, such as Federation of Young Democrats-Hungarian Civic Alliance (FIDESZ) and the Movement for a Better Hungary (JOBBIK) in Hungary, Law and Justice (PiS) in Poland, the British UK Independence Party (UKIP), the French National Front (FN), or the Dutch Party for Freedom (PVV), populist parties can be found on the other side of political spectrum, like the Coalition of the Radical Left (SYRIZA) in Greece, PODEMOS in Spain, the Left Block (BE) in Portugal, and so on.

An analysis of the programs and the plans of action of the above mentioned parties is fundamental to dismount the first myth and to understand that populism is

\footnotetext{
Footnote 7 continued

was required as it represented the best way to fight against right populism. As it is known, Laclau and Mouffe's populism concept is mainly based on the study of populism in Argentina under Juan Perón and Brazil ruled by Getúlio Vargas. Studying some cases in the same continent, Kurt Weyland came to quite different conclusions as he considered left-wing populism as a threat for democracy. In 2015, Slavoj Žižek wrote an article declaring his support to Syriza, Podemos, and the Latin American populism, after an interview first published in Mexico where his opinion seemed to be quite different.
} 
not an ideology, even if Taggart (2003:7) defends populism as "attached to some very different ideological positions from the left to the right". A sentence that dispels once again the second myth.

The programmatic content analysis allows verifying the simultaneous existence of measures that, from the ideological point of view, represent different ways of conceiving the reality. The ideology can become a dark chamber, far from reflecting the reality. Ideology that as Santos (1977:208) explained is also an ambiguous word. ${ }^{8}$

More difficult is to dispel completely the third myth, as multiple cases of identification of a populist party with its leader can be found. Indeed, to refer to PODEMOS, it is to remember Pablo Iglésias; the same about National Front and Marine Le Pen, PVV and Geert Wilders, SYRIZA and Tsipras, FIDESZ and Orbán, and so forth.

Besides the myths pointed out, there are two more that, in my opinion, deserve to be mentioned. Therefore, it is usual to relate the new populist outbreak with the crisis that started as financial before spreading to the other sectors. The austerity measures demanded a high social cost, reduced solidarity and promoted individualism, and selfish goals, forgetting collective happiness. Such situations are generally seen as responsible for the failing confidence of the citizens upon the political elite, accused of serving the economic interests.

Judis (2017:109) considers that in the north of Europe where the big recession was not so strong, and where many of those who required political asylum were concentrated, the right-wing populism dominated, while in south Europe, countries with high unemployment rates, such as Greece, Italy, or Spain, developed a leftwing populism. The economic element seems responsible for the appearance of two different types of populism. A typology accepted by many left-wing populist leaders, because they consider left populism as revolutionary and right populism as reactionary.

However, how do we explain the low level of populism in countries hardly affected by the crisis? Or a strong or, at least, considerable populism in countries where almost no crisis was felt? Examples of both the situations can be found in the European Union. Besides, in a country, right-wing and left-wing populism can coexist. For example, in the EU most important country, Germany, left-wing populism represents $8.6 \%$, but right-wing populism reaches $6 \%$.

Another myth consists in defending the existence of an inevitable link between populism and two other phenomena: nationalism and regionalism. Admitting the possibility of a relationship between populism, nationalism, and regionalism, it is necessary to say that we are confronting three different concepts, though having some common elements, a situation that increases the difficulty of a clear distinction. In addition, the separation of the three concepts gets worse when we

\footnotetext{
${ }^{8}$ The author considers that the concept has been used with the theoretical function of: process in false conscience (Engels), wrong conception and complete abstraction of History (Marx), distorted knowledge (K. Mannheim), false conscience (K. Korsch), conception of the world (Gramsci), element of social covering with mystifying content (Meynaud), mystifying representation ( $\mathrm{H}$. Lefebvre), system of opinions (Schaff), system of representations (Althusser), set with relative coherence of representations (Poulantzas), and so on.
} 
analyze the political discourses, because politicians usually merge them. On one hand, regionalism and nationalism use populist speech, because it appeals to the people. It is a targeting strategy. It is important to reach the people, even when the party invents a "Nation", as it happened in Italy where the Lega Nord invented Padania that "theoretically came into being independent when it was declared sovereign and independent on 15 September 1996", through a "well-publicised party demonstration that took place along the River Po" (Giordano 2000:457). On the other hand, the populist leaders do not mind using regionalist and nationalistic flags, since they serve populist interests. The attitude of many populist leaders toward immigrants, mainly Muslims, and refugees constitutes a good-or a badexample of such use. A self-interested religiosity advocated by some politicians plays up the role of the church in the national culture even when they forget all about going to Mass.

An example of the contact points among populism and nationalism is when Jagers and Walgrave (2005) include exclusionary populism in their typology. Indeed, when the political speech is against the presence of out-groups, we can say that we are facing a nationalist demonstration. However, when the defence of the homeland represents a way to attack the ruling elite, responsible for the arrival of immigrants and refugees, populism replaces nationalism.

Therefore, populism functions at another level. Populism is more than a fashion or style. It is on a different dimension: the fight for internal hegemony. Populism is not separatist and it must not be equated with the irredentism. It tries to influence and it looks for the internal power.

Hence, a populist party does not necessarily require appealing to regionalist or nationalistic sentiments. Its interest lies in picking on issues which are prone to creating internal divisions and to discrediting the ruling class. As History proves, the mainstream parties tend to keep such issues for a later debate or postpone them indefinitely.

As time never stops and it never forgives those who waste it, it is the moment to get to the core of the issue. That one indicated in the subtitle of the present article.

\section{Populist Dynamics in the European Union}

In 2017, authoritarian populist parties participate in governments in seven European Union countries: Hungary, Poland, Greece, Finland, Latvia, Lithuania, and Slovakia. Besides, they act as support to the ruling parties in Denmark, Bulgaria, and Portugal. A populist presence impossible to be hidden and a situation that political studies cannot ignore or underestimate.

One logical way of handling the theme of populist dynamics in EU is to crosscheck countrywise the data of the Index of Democracy and the Authoritarian Populism Index. The first index is elaborated for the Economist Intelligence Unit of London based on 60 variables grouped in five categories: the electoral process and pluralism, the civil freedoms, the functioning of the government, the political participation, and the political culture. The index contemplates four levels: full democracies, flawed democracies, hybrid regimes, and, at the bottom far away 
from democracy, the authoritarian regimes. ${ }^{9}$ This is not the only index about democracy. For example, the classification made by Freedom House could be an option, but as Diamond (2015:155) warns, the five criteria ${ }^{10}$ of this independent watchdog organization dedicated to the expansion of freedom and democracy around the world has led to a somewhat expansive and generous list of democracies. The second index is prepared by Andreas Johansson Heinö, a member of Timbro Foundation, and it quantifies populism in a percentile scale from 0 to $100 .{ }^{11}$

Accepting that populism represents a threat to democracy, it will be expectable that the European Union countries where the populist phenomenon is not visible will be considered as full democracies, while the EU members where populism is increasing will present the lowest values in what concerns the quality of the democracy. Referring to the level of authoritarian populism in EU members, in 2016, the endnote shows a big difference between the top and the bottom. ${ }^{12}$ The three countries where populism was very high: Hungary-66.4, Greece-57, and Poland $-46.4 \%$ had a little to compare with, at least, eight countries: Lithuania8.5, Estonia-8.3, Croatia-7.8, Belgium-7.4, Ireland-4.1, Slovenia-2.2, and Luxembourg- $1.6 \%$, countries where populism did not reach two digits, and Malta, a country free of populism.

Returning to Jagers and Walgrave (2005), they presented a typology containing four types of populism according to the construction of people, the anti-elitism, and the exclusion of outside groups. They called empty populism to the lowest level

\footnotetext{
${ }^{9}$ The scale is: 0 to 4 -authoritarian regime, 4 to 6 -hybrid regime, 6 to 8 -flawed democracy, and 8 to 10-full democracy.

${ }^{10}$ Larry Diamond identified the five criteria. To be classified as democracy a country should score (a) at least 7 out of 12 on the "electoral process" dimension of political rights; (b) at least 20 out of 40 overall on the raw point scale for political rights; (c) the most recent parliamentary and presidential elections were reasonably free and fair; (d) there are no significant hidden sources of power overriding the elected authorities; and (e) there are no recent legal changes abridging future electoral freedom.

${ }^{11}$ On the pages 14 and 15, the author explains the methodology that he followed. Two indicators are used to measure influence. "First, the total amount of mandates. The index shows how many mandates are held each year by representatives of authoritarian parties. This measure naturally only includes those parties that managed to secure mandates. Parties like Front National or the United Kingdom Independence Party have been relatively successful when it comes to numbers of votes, but as a result of the French and British election systems, they have not been able to convert this into anything more than limited parliamentary presence. The second indicator is participation in a government. In addition to measuring election results and number of mandates (114 of the parties have won mandates at some point), I have classified the parties as "left-wing" and "right-wing" and as "authoritarian" or "totalitarian". RightLeft is primarily dependent on the parties' own classification. In doubtful cases, I have followed the most commonly used designations used in the secondary literature, and in a few, particularly difficult cases, I have used the parties' choice of collaborators to decide. These cases, however, are so few that a potential error in classification is of no real significance for the main results. The division into authoritarian and totalitarian depends on the parties' view on democracy. Only explicitly anti-democratic parties have been classified as anti-democratic. If a party contains Nazism, fascism, communism, Trotskyism, Maoism, etc., it is a totalitarian party".

12 Values in descending order according to overall score: Hungary-66.4; Greece-57; Poland -46.4; Italy-33.7; Cyprus-29.4; Denmark-28.9; Austria-25; Czech Republic-22.7 France-21.7; Spain21.2 Portugal-20.5 Finland-18.2; Latvia-16.6; Romania-15.3; Germany-14.6; Sweden-12.9; United Kingdom-12.6; Netherlands-10.1; Lithuania-8.5; Estonia-8.3; Croatia-7.8; Belgium-7.4; Ireland-4.1; Slovenia—2.2; Luxembourg-1.6; and Malta -0 .
} 
where we can only find references to the people. ${ }^{13}$ According to the Authoritarian Populism Index, none of these types was present in Malta and as this country was a full democracy the first part of the hypothesis seems to be proved. The absence of populism was accompanied by a high Democracy Index - 8.39, which means that, excepted for the political participation-6.11, all the parameters were high: 9.71 for the civil freedoms, followed by the electoral process and pluralism-9.17, the political culture-8.75, and the functioning of government-8.21. However, as hurry is never a good counsellor, no conclusion should be drawn before presenting all the Index of Democracy data.

In the European Union of 2016, there was neither hybrid nor authoritarian regimes, since 11 members of the community belonged to full democracies and seventeen to flawed democracies. The full democracies were: Sweden-9.68; Denmark-9.20; Ireland-9.15; Finland-9.03; Luxembourg-8.81; The Netherlands-8.80; Germany-8.63; Austria-8.41; Malta-8.39; United Kingdom8.36; and Spain-8.30. As the values suggest, none of these countries was at risk of falling to a lower level.

One aspect to be emphasized is that none of the countries that once belonged to the East Block is yet considered full democracy. The transition from a model in which everything was supervised or controlled by the Communist Party to a model based on private economic initiative was difficult. The civil society was not prepared for the change. The reality hidden behind the wall was worse than what the western minds could imagine, even when "a number of well-educated persons with impeccable political credentials from the communist point of view" in 1982 were sent to US with "scholarship grants by the Central Committee of the Slovenian Communist Party" to study "stock exchanges or investment banking and public finances, institutions that characterize the democratic societies" (Umek 2008:117). ${ }^{14}$ This was just the exception that confirms the rule during the cold war period.

The 17 flawed democracies included: Italy-7.98; France-7.92; Portugal7.86; Estonia-7.85; Czech Republic-7.82; Belgium-7.77; Cyprus-7.65; Slovenia-7.61; Lithuania-7.47; Latvia-7.31; Slovakia-7.29; Greece-7.23; Bulgaria-7.01; Poland-6.83; Croatia-6.75; Hungary-6.72; and Romania6.62. The data showed that this group was far from homogeneous, because five countries were near the higher level, while some others were not far away from the hybrid regimes.

After crossing the data of the two indexes, the first part of the presumption was confirmed again, because besides Malta, Luxembourg was the EU country with the

\footnotetext{
13 The other three types are: exclusionary populism, when there is the exclusion of out-groups; anti-elitist populism, when the appeals to the people are combined with attacks on elites and complete populism, when the three elements - appeals to the people, exclusion of out-groups, and attacks on elites-are present.

14 Umek (2008:118) considered that "when the changes to the economy and the political system were introduced, they gained momentum" as they had "developed quickly and not always according to the wishes of the ruling communist parties". The same author also says that these well-educated people became "the predominant owners in their national economies through privatisation processes that they controlled (Umek 2008:115).
} 
second lower populism level, an almost residual value. It was also a full democracy with the Index of Democracy at 8.81. In fact, in 2016, only the political participation-6.67 did not follow the rule of a very high evaluation: 10 , or the maximum, for the electoral process and pluralism, 9.71 for the civil freedoms, 8.93 for the functioning of government, and 8.75 for the political culture.

However, the second part of the presumption was not confirmed, because in the EU country that Heinö places in the first place, Hungary, populism reached $66.4 \%$ in 2016 with the right-wing making the greatest contribution- $65.2 \%$, but it continues to belong to the flawed democracies, occupying the 56th position in the Index of Democracy, with 6.72, and with only one negative parameter: the political participation-4.44. All the other parameters were positive and one of them was strongly high -9.17 for the electoral process and pluralism. Those below were the civil freedoms - 7.06, the only element falling, the political culture-6.88, and the functioning of government-6.07. Compared with 2015, the Index of Democracy came down, because of the fall of the civil freedoms, an element that must be taken in account, because as Bozóki (2015:27) affirms, when Orbán won the power he restructured the political system, modifying the Constitution and giving the Government enormous de facto power. He nominated members of the party to independent institutions, started a campaign against the intellectuals, and handed over all major government-promoted businesses "to entrepreneurs close to Fidesz or allies of the prime minister". Besides, "alternative artists, actors, and actresses became targets of populist propaganda". A time to reward friends and for harassment and punishment to foe.

Orbán's electoral campaign was marked by five words: "work, home, family, health, and order", for the defence of a "new social contract" or a "revolution, declaring the need for fundamental political changes required presumably by the "will of the people" (Bozóki 2015:26). However, there was a big distance between the campaign promises and the measures that were taken by his government and the people, in whose name everything was said to be done, were obliged to suffer the consequences of the governmental measures, because by introducing "a flat tax system, the cabinet aimed to win the support of the wealthy against the interests of the poor", while "welfare benefits for the homeless and unemployed have been cut from 6 to 3 months only" (Bozóki 2015:27).

A right-wing populism forgets the people and it is believed to become a threat for democracy, as it tries to capture the power. A disturbing situation or a worrying development in a context in which the party leading the opposition, Jobbik, is rightwing populist, as well. An electoral choice dominated by populist parties. As Wolff (1996) verified, nowadays, representative democracy is facing the same problem that occurred when Plato invented his perfect city: how can electors preserve democracy and protect themselves against those politicians who become undesirable when they reach the power?

However, as we said earlier, the right-wing does not monopolize populism in the European Union. In fact, the second country with a high degree of populism is Greece, since Syriza took over the government. Syriza used the crisis to discredit the previous governing elite, while at the same time demonizing the external institutions. It is the essence of populism. However, once in power it adopted a 
relatively moderate discourse, effecting mere semantic changes to meet the reality. It even formed - and repeated - a governmental alliance with a party belonging to the other side of the ideological spectrum.

According to the Index of Authoritarian Populism, Greece presented, in 2016, a value of $57 \%$, with the left-wing responsible for the biggest average-45.1\%, while the right-wing contributed $11.9 \%$. However, the Index of Democracy included Greece in the group of flawed democracy countries. It occupied the 44th rank with a value of 7.23. In this index, the highest points belonged to the electoral process and pluralism-9.58, followed by the civil freedoms-8.82, very far away from the political culture-6.25, and the political participation-6.11. The functioning of the government held the lowest parameter-5.36.

It should be emphasized that, following the example of Hungary, also in Greece, the quality of democracy fell as compared to 2015 when the index was 7.45. It went down on two parameters: the civil freedoms and the political participation. However, it is possible to say that the rising populism, from the right-wing in Hungary and from the left-wing in Greece, was not decisive for these countries to be excluded from being classified as flawed or incomplete democracies. The conclusion will not change if the analysis is extended to the third country with high populism, namely Poland. As a matter of fact, Poland was also a flawed democracy with only one negative parameter, the political culture-4.38. All the other parameters were high or acceptable: 9.17 for the electoral process and pluralism, 8.24 for the civil freedoms, 6.67 for the political participation, and 5.71 for the functioning of government. However, both the electoral process and pluralism and the civil freedoms were lower than in 2015, because the populist party, PiS, "ordered a major purge of public radio and television, and abolished the political neutrality of the civil service" (Rupnik 2016:79). As Moreira (2001) denounces, the ruling elite likes to be obeyed and it hates those who dare to disagree. An endless fight between the word of the power and the power of the word.

Probably, fact prods us to bring a new element into the debate: the satisfaction with democracy as a measure of quality of democracy. It is something that goes beyond the level of satisfaction with the functioning of the government as this is just one of the categories of the Index of Democracy. Meneguello (2010:143) who had the Brazilian society in mind, defended that for citizens, there was no a direct association among satisfaction with democracy, the actuation of the institutions, and the results of public policies. However, even accepting that the degree of satisfaction with democracy does not result only of the functioning of the government, this last element counts for the evaluation of the quality of democracy.

Therefore, these data will have two very distinct readings, depending upon the populist parties being in the government or in the opposition. In the first case, if the dissatisfaction is great, it will be the performance of the ruling populist parties that is at stake. In the second case, the presence of a higher degree of dissatisfaction will make populism appear as solution against the discredit of the current system, in which "apathy and inertia" of the mainstream parties "could significantly lower the barriers to new democratic reversals and to authoritarian entrenchments in many 
more states" (Diamond 2015:153). As it is well known, democracy is a recent reality in many EU countries.

Or, as can be seen in the most recent Eurobarometer $86^{15}$ that evaluated this item, the country where the voters showed to be less satisfied with the functioning of the democracy-21\% — was Greece. An average that does not play in favour of Syriza's populism, the populist party that, for two consecutive times, deserved the preference of an electorate that had no faith in the ancient establishment parties. In addition, the country of the European Union with the highest populism rate, namely Hungary, was well below the satisfaction average, which remained $42 \%$. The case of Fidesz was similar to that of Syriza. Incidentally, Italy and Cyprus, ranking as 4th and 5th with more populism, also appeared in the lowest rank for satisfaction with democracy-33 and $37 \%$, respectively, but as these countries were not led by populist parties, the burden of responsibility fell on mainstream and ruling parties.

Thus, it seemed possible to say that the countries with the highest populism, both in the government and in the opposition, were those where the citizens were more displeased with the functioning of the democratic institutions. However, we see some data that disagree with the above conclusions. Indeed, a country of high level of populism, Denmark, was the second one where citizens were the most satisfied with democracy-87\%. The same happened in other states where populism was strongly increasing, but citizens did not complain about democracy: Sweden-79\% of satisfaction, Finland-73\%, and Germany-69\%. By the way, the 20 parliamentary seats won by Geert Wilders' party in the latest electoral act in The Netherlands proved that nowadays, populism plays an important role in the country. However, $78 \%$ of the inhabitants were satisfied with the functioning of democracy. In this group of countries, only in Finland, the populists are nowadays part of the governmental elite. A former Finish Prime Minister, Harri Holkeri, wrote that in Finland the populist parties do not face so much contempt as in other countries, but it seems possible to say that it is not-only or over all-the dissatisfaction with the functioning of the democracy that explains the growth of populism.

To conclude the analysis, it is time to reflect on the relationship between economic crisis and the populism growth. The study of the data concerning the per capita income, that is, the identification of the countries that produce more or less wealth per person in parity of the purchase power, allows us to draw some conclusions regarding this relationship. Thus, a first confirmation: all the members of the EU had a downward trend in 2009, though in Poland, Greece, and Portugal, this breaking had started in the previous year. A second noteworthy element is that almost the totality of the countries has started to recover in 2010, while only Greece had to wait until 2013 to initiate the recovery. Moreover, this trend of growth was steady in the great majority of the cases until 2015. Only in Finland, Croatia, and Slovenia by 2013, in Luxemburg by 2012, in Portugal by 2011, and in Spain by 2012 and 2013, it was not so.

\footnotetext{
15 Values in descending order according to overall score: Denmark-91; Luxembourg-87; Sweden79; Netherlands-78; Finland-77; Ireland-73; Belgium—69; Germany-69; Malta—64; Austria—64; United Kingdom-64; Poland—57; Czech Republic-53; Average Percentage-53; Latvia—52; Portugal-52; Estonia-51; France-45; Slovakia-43; Lithuania-42; Hungary-42; Spain-39; Romania-38; Croatia-37; Cyprus-37; Slovenia-36; Italy-33; Bulgaria-30; and Greece-21.
} 
The data presented do not allow a link between the crisis and populism, and the situation does not change if the five countries with highest and lowest per capita income are included in the list. In fact, the group of countries with higher incomeLuxembourg, Ireland, The Netherlands, Austria, and Germany-includes countries where the index of Authoritarian Populism is very different-1.6; 4.1; 10.1; 25, and $14.6 \%$, respectively. In the same way, the five countries with lower per capita income-Hungary, Latvia, Croatia, Romania, and Bulgaria-present different levels of populism-66.4; $16.6 ; 7.8 ; 15.3$, and $17.5 \%$, respectively.

Therefore, it is not possible to establish a linear correlation between the economic crisis and populism. The reason for the new outbreak of populism must be searched elsewhere. Probably, in the human nature more than in the human condition, but before concluding, there is still a last element: the relationship between media, net, and populism. It is an important issue, because nowadays, communication plays no more only an instrumental role serving the traditional three pillars of Political Theory: Political Philosophy, Sociology and Law.

\section{Media, Net, and Populism}

The relationship between media and populism is ambiguous. Therefore, it is commonplace to hear that populism is just a media invention, but it is also said that the media are important to fight against populism. Besides, Mazzoleni (2008:50) speaks about "media complicity", because "in many instances, the European media appear to have contributed to a legitimization of the issues, keywords, and communication styles, typical of populist leaders".

Mondon (2015:145-146) agrees with Mazzoleni, recognizing that while the media are "rarely sympathetic to the cause of populist nativist parties, their excessive coverage reinforces their status as both legitimate and the " real" alternative to the status quo, the "outsider" in opposition to the elite". To prove the final part of the sentence Mondon says that "this kind of coverage and legitimization have been particularly striking in France and the United Kingdom", because in these two countries, the leaders of National Front and UKIP, Marine Le Pen, and Nigel Farage, "have become regular features on prime time television and front pages". In what concerns to UKIP, it is noteworthy that the regulator and competition authority for the UK communications industries, Ofcom, decided that the populist party should be treated as a major party during the campaign for the 2014 European Parliament election. A decision that allowed Farage a bigger prominence.

Obviously, more examples could be pointed of this populist presence in the media in spite of populist leaders complaining that they are ignored by the media. As Norocel (2017:48) noticed, in Finland, during 2011 campaign, Finns Party "accused the mainstream media of being a subservient tool in the service of mainstream political parties" and "it succeeded in consolidating the perception among the citizens that it was the political voice that went unheard and neglected by the media" the very same media that "the party was highly visible in". That situation was not true only in Finland. Populist parties know how to use negativity 
and complaints in political communication. Nothing is left to chance. Everything is strategically prepared. Victimization as a source of profits.

However, there exist also cases of effective marginalization. According to Jagers and Walgrave (2005), in Belgium, the established parties built a cordon sanitaire against Vlaams Blok, once this party was accused of being "racist, fascist, and undemocratic" and De Cleen and Van Aelst (2017:103), using De Swert (2001) as source, did not deny that "although there has never been a cordon sanitaire médiatique, most media outlets (in varying degrees) have not treated the VB as an ordinary party". A discrimination that "the public broadcaster VRT explained" on a "special note on its democratic role". The example was followed by newspapers in 2003, in the election day, when De Standaard "gave five potential reasons to vote for each political party, but explicitly mentioned that there were no reasons to vote for VB". Yet, this double marginalization did not function, because Vlaams Blok obtained 767,605 votes corresponding to $11.6 \%$ and 18 deputies, more 154,206 votes, and three deputies than in 1999 legislative election.

As History proves, the leaders know that image and propaganda play a useful and important role. Nobody can forget the role played by Leni Riefenstahl in the promotion of Nazi regime. Some years later, television allowed "populists to reach their followers 'in person'. Chávez hosted a regular Sunday talk show" (Weyland 2013:20). Public television supervised and controlled by the ruling party. Space for the opposition shrank or even disappeared. An ideological inculcation. Presenting the reality through the power eyes. The official truth.

In Italy, Berlusconi may be presented as the best symbol of a populist leader in a conjuncture in which information belonged to the small political and economic elite. A leader who demanded "that identification was never with the party but with him", because he considered himself as "the one" who represented "the interests of Italian people (Woods 2014:44). Berlusconi was Fininvest owner, the business group that controlled Mediaset, the biggest Italian mass media group, owning television channels, radios, and content production companies. The 1994 political campaign was programmed and played by Publitalia, Fininvest́s publicity enterprise, "with a key role being played by its head, Marcello dell'Utri” (Ruzza and Fella 2009:143). Publitalia was so present in the campaign that it had the mission "to choose the candidates for the 26 electoral circles" (Santos 2012: 293).

However, in Italy, a new paradigm was discovered. Beppe Grillo, an ancient comedian, and Gianroberto Casaleggio founded MoVimento5Stelle, as a no-party, because they discovered that mass media only allowed "one to many" communication model, which needed to be replaced by a "many-to-many" model. As the electoral results are proving, the digital citizenship has already arrived. It has surprised the traditional parties whose leaders thought that they were dealing with an epiphenomenon. It was just a project that mobilized young people in a continent that is aging. A mistake because, according to Lanzone and Woods (2015:60), M5S "has attracted a younger base of support than the main political parties", but "the evidence indicates that movement's key demographic support are Italian men in their mid-40s with a relatively high degree of interest in political and social issues". 
An element that is noteworthy is that Grillo's idea was followed by other European countries. In the European Parliament, a new group was formed-Europe of Freedom and Direct Democracy. A group including 20 members elected by UKIP, 15 by MoVimento 5 Stelle, 2 by Sweden Democrats, 1 by Alternative for Germany, 1 from Poland, 1 from Lithuania, 1 from Czech Republic, and 1 independent from France.

The net is more powerful than the traditional mass media. The populist message can be broadcast continuously. No intermediary agents are required. The actions of the political caste can be immediately denounced. The border line between "us" and "them" is constantly noticed. Populist truth is a click away and almost everybody is always on line. This is a reality that goes beyond the borders. Suiter (2015:299) said that almost everywhere "candidates use social media including Twitter and Facebook to market, to mobilize and to engage with their supporters and the general public", and Pajnik and Sori (2015:48) came to the same conclusion saying that "populist leaders are highly present on line; they are keen users of the Twitter and writers of blogs". Donald Trump, both during the electoral campaign and after becoming President of the United States of America, represents a good example of this way of making politics.

At last, it is important to mention that Benjamin De Cleen and Van Aelst (2017:102) studied the relationship between mass media and populist parties according to "two partly overlapping strands of analyses: populist parties and the media, and the populism of the media". The final part of the sentence is clear. Media is responsible for its own populism. A situation confirmed by Mazzoleni et al. (2003:8) though considering that there exists a difference between the attitude of elite media and popular media. ${ }^{16}$ A position that is far from consensual. On one side, we can say that when the media cause emotions participating on the critics against mainstream political parties and politicians accusing them of incompetence, they are drawing a line between the elite and the real people, the basis of populism. On the other side, we can consider that this role played by media only intends to capture audience and that market hegemony is different of fighting for power hegemony.

Nowadays, media are increasingly market-driven. Therefore, public interest is replaced by the momentary interest of the public, the new designation of the citizen in an evolutionary process in which public will give way to a broader conceptaudience. That is why Schultz (2004:218) says that audiences are no more seen as citizens to inform but as consumers to attract. Political legitimacy is changing. Some years ago, the discussion was between the ethic of conviction and the ethic of responsibility. Now, a floating legitimacy is taking over. The evaluation is permanent. More than direct or representative democracy, it is time to think about deliberative democracy. A concept deeply worked by Habermas (1992) and developed by Santos (2017).

\footnotetext{
${ }^{16}$ Popular media use "to focus more obviously on the personality traits of political actors, on entertainment values, or on the details of conflicts, rather at the level of gossip, than at the level of serious analysis".
} 


\section{Conclusion}

This article tried to present populism deconstructing its myths as well as to show the reality of populist parties and movements in the European Union, to get an answer to the central issue, i.e., is populism a threat or a challenge to democracy? An ambivalent question even considering that a threat can become an opportunity.

Isaiah Berlin (2006:149) said that the people that tend to protest in reactionary societies usually dedicate their energy to activities such as higher studies and liberal/professional occupations when living in democratic and relatively open societies. However, this rule allows exceptions due to human nature, mainly when a negative vision is presented. ${ }^{17}$ As Pascal (1922) said, being neither angel nor animal is being human. However, in spite of this double difference, humans suffer from the limitations of the animal and dream as the angel. Or the devil, as History has often proved to be true. As it is impossible to satisfy everybody when the protest becomes commonplace, the gap between people and elite increases and it needs to be filled. It is then that the differential logic is replaced by the equivalential one and populism becomes more visible.

Therefore, our findings seem to lead us to conclude that democracy without populism is almost an impossibility. There will be always reasons for fighting: internal antagonisms, defence of an equivalential logic. On the other hand, populism without democracy is not an inevitability but only a possibility as the measures adopted by the ruling populist leaders, for instance in Hungary and Poland, prove.

In what concerns Belgium, De Lange, and Akkerman (2012:45) believe that "the quality of the democratic process in Belgium does not seem to suffer greatly from the emergence of populist parties", because "the negative effects that the emergence of populist parties has had on liberal democracy are offset by positive effects". What were those positive aspects? Just "an increase in the responsiveness of the established parties, at least in the electoral arena, has to some extent revitalized Belgian politics". A sentence denouncing that the performance of traditional parties falls below citizens' expectations and so populism can be seen as an opportunity to democracy.

Adriano Moreira (2007:195), influenced by Teilhard de Chardin, ${ }^{18}$ opined that the international community was starting to obey to an increasing complexity law, because, as the number of public and private decision centres was growing (principle of dispersion), there would be a quantitative and qualitative developments of relationship among them and this process leads to the institutionalization of greater coordination (principle of convergence). The wrong way as European Union deals with this prevision can also partially explain populist dynamics in the community as the regional integration has been made without asking people's opinion.

\footnotetext{
${ }^{17}$ For example, St. Augustine identified three negative features in the human nature: cupidity, passion for power, and sexual desire, and Thomas Hobbes identified three reasons for conflict: competition, suspicion, and vanity. According to Hobbes, the man never stops, because he is afraid of losing what he has already got.

18 The first Brazilian edition in 1975.
} 
Is populism a shadow of democracy? Is democracy a populist shadow? Diamond (2015:154) defends that "it is vital that democrats in the established democracies not lose faith". Agreeing with this appeal, I believe that faith is necessary, but not enough. The quality of the performance of the elected members has the final answer.

\section{References}

Berlin, Isaiah. 2006. O poder das ideias. Lisboa: Relógio d' água.

Bozóki, András. 2015. The illusion of inclusion: configurations of populism in Hungary. In Thinking through transition. Liberal democracy, authoritarian pasts and intellectual history in East Central Europe after 1989, ed. M. Kopecek, and P. Wcislik, 275-312. Budapest/New York: Central European University Press.

Canovan, Margaret. 1999. Trust the people! Populism and the two faces of democracy. Political Studies XLVII: 2-16.

De Cleen, Benjamin, and Van Aelst, Peter. 2017. The rise and fall of populism research. In Populist political communication in Europe, ed. T. Aalberg, F. Esser, C. Reinemann, J. Stromback, and C. De Vreese, 99-110. New York: Routledge.

De Swert, Knut. 2001. Tussen vergeetput en schandpaal: strategieën tegen extreem rechts in drie Vlaamse kranten. (Working paper). Antwerp, Belgium: Departement Politieke en Sociale Wetenschappen, Universiteit Antwerpen

Diamond, Larry. 2015. Facing up to the democratic recession. Journal of Democracy 26 (1): 141-155.

Donald, MacRae. 1969. Populism as an ideology. In Populism. lts meaning and national characteristics, ed. G. Ionescu, and E. Gellner, 153-165. London: Wiedenfeld and Nicholson.

Giordano, Benito. 2000. Italian regionalism or "Padanian" nationalism—the political project of the Lega Nord in Italian politics. Political Geography 19: 445-471.

Habermas, Jürgen. 1992. Faktizität und Geltung-Beiträge zur Diskurstheorie des Rechts und des demokratischen Rechtsstaats. Frankfurt: Suhrkamp.

Hawkins, Kirk. 2009. Is Chavez populist? Measuring populist discourse in comparative perspective. Comparative Political Studies 42 (8): 1040-1067.

Jagers, Jan, and Walgrave, Stefaan. 2005. Populism as political communication style. An empirical study of political parties' discourse in Belgium. European Journal of Political Science 46 (3): 319-345.

Judis, John. 2017. A explosão do populismo. Lisboa: Editorial Presença.

Knight, Alan. 1998. Populism and neo-populism in Latin America, especially Mexico. Journal of Latin American Studies 30 (2): 223-248.

Laclau, Ernesto. 1977. Politics and ideology in marxist theory: capitalism-fascism-populism. London: Verso.

Laclau, Ernesto. 2005. La razón populista. México: Fondo de Cultura Económica.

Laclau, Ernesto. 2015. Política e ideología en la teoría marxista. Capitalismo, fascismo, populismo. Madrid: Siglo XXI de España Editores.

Lange, Sarah, and Akkerman, Tjitske. 2012. Populist parties in Belgium: a case of hegemonic liberal democracy? In In populism in Europe and the Americas. Threat or corrective to democracy, ed. C. Mudde, and C. Kaltwasser, 27-45. Cambridge: Cambridge University Press.

Lanzone, Lisa, and Woods, Dwayne. 2015. Riding the populist web: contextualizing the Five Star Movement (M5S) in Italy. Politics and Governance 3 (2): 54-64.

Mazzoleni, Gianpietro, Stewart, Julianne and Horsfield, Bruce (eds.). 2003. The media and neo-populism: a contemporary comparative analyses. Westport: Praeger Publishers.

Mazzoleni, Gianpietro. 2008. Populism and the media. In Twenty-first century populism, ed. D. Albertazzi, and D. McDonnell, 49-64. London: Palgrave Macmillan.

Meneguello, Rachel. 2008. Aspectos do desempenho democrático: estudo sobre a adesão à democracia e avaliação do regime. In Democracia e confiança. Por que os cidadãos desconfiam das instituições públicas, ed. José Álvaro Moisési. São Paulo: EdUsp.

Mondon, Aurelien. 2015. Populism, the "people" and the illusion of democracy-The Front National and UKIP in a comparative context. French Politics 13 (2): 141-156.

Moreira, Adriano. 2001. Ciência Política. Coimbra: Almedina. 
Moreira, Adriano. 2007. A comunidade internacional em mudança. Coimbra: Almedina.

Mudde, Cas. 2004. The populist Zeitgeist. Government and Opposition 39 (4): 541-563.

Mudde, Cas, and Kaltwasser, Cristobal. 2017. Populism: a very short introduction. Oxford: Oxford University Press.

Norocel, Ov C. 2017. Finland: from agrarian to right-wing populism. In Populist political communication in Europe, ed. T. Aalberg, F. Esser, C. Reinemann, J. Stromback, and C. Vreese, 42-53. New York: Routledge.

Pajnik, Mojca, and Sori, Iztoc. 2015. Populist communicative strategies. Fostering "the web of exclusion" in European societies. In Engagement against violence. Tools for media and citizenship education, ed. M. Ranieri, 47-63. Ariccia: Aracne Editrice.

Pappas, Takis. 2013. Analysis by Takis Pappas. In The rise of populism and extremist parties in Europe, ed. I. Durant, and D. Cohn-Bendit, 28-30. Bruxelas: The Spinelli Group.

Pappas, Takis. 2014. Populist democracies: post-authoritarian Greece and post-communist Hungary. Government and Opposition 49 (1): 1-23.

Pareto, Vilfredo. 1917. Traité de Sociologie Générale. Paris: Librairie Payot \& C.ie.

Pascal, Blaise. 1922. Pensées de Pascal. Paris: Garnier.

Pinto, José. 2017. Populismo e democracia. Dinâmicas populistas na União Europeia. Lisboa: Sílabo.

Rupnik, Jaccques. 2016. The specter haunting Europe. Surging illiberalism in the East. Journal of Democracy 27(4): 77-87

Ruzza, Carlo, and Fella, Stefano. 2009. Re-inventing the Italian right: territorial politics, populism and "post-fascism". New York: Routledge.

Santos, João. 1977. A questão da ideologia: de «A Ideologia Alemã » aos «Cadernos do Cárcere » . Separata de Biblos, LIII. Coimbra: Faculdade de Letras da Universidade de Coimbra.

Santos, João. 2012. Media e poder. Lisboa: Vega.

Santos, João. 2017. Crise da Representação ou Mudança de Paradigma? Democracia, Deliberação e Decisão. Revista Portuguesa de Filosofia 73 (1): 15-48.

Schultz, David. 2004. From saxophones to Schwarzenegger: entertainment politics on late-night television. In Lights, camera, campaign! Media, politics and political advertising, ed. D. Schultz, 215-238. New York: Peter Lang Publishing Inc.

Suiter, Jane. 2015. Political campaigns and social media: a study of \#mhe13 in Ireland. Irish Political Studies 30 (2): 299-309.

Taggart, Paul. 2003. The populist turn in the politics of new Europe. Paper prepared for presentation at the 8th biannual international conference of the European Union Studies Association Conference, Nashville, 27-29 March 2003.

Umek, Andrej. 2008. Post-communist tendencies in Central and Eastern Europe. European View 7: $115-120$.

Weyland, Kurt. 2001. Clarifying a contested concept: populism in the study of Latin American politics. Comparative Politics 34 (1): 1-22.

Weyland, Kurt. 2013. Latin America's authoritarian drift. The threat from populist left. Journal of Democracy 24 (3): 18-32.

Wiles, Peter. 1969. A syndrome, not a doctrine: Some elementary theses on populism. In Populism. lts meaning and national characteristics, ed. G. Ionescu, and E. Gellner, 166-179. London: Wiedenfeld and Nicholson.

Wolff, Jonathan. 1996. An introduction to political philosophy. Oxford: Oxford University Press.

Woods, Dwayne. 2014. The many faces of populism in Italy: the Northern League and Berlusconism. Research in Political Sociology 22: 27-51.

José Filipe Pinto is member of the International Academy of Portuguese Culture and full Professor, Coordinator, and Senior Researcher in the Department of Political Science, Security and International Relations of Lusophone University of Humanities and Technologies of Lisbon. He has a Ph.D. in Sociology and Aggregation in Political Science. He was the Director of the courses of Master in Diplomacy and International Relations, and of Master in Political Science, Citizenship and Governance from July 2012 to July 2015. His research focuses on comparative political systems, leadership, governance, globalization studies, Community of Portuguese Language Speaking Countries, International Relations, and European Union. His most recent book, published in April 2017, is Populism and democracy. Populist dynamics in the European Union. 